CommentaRy on COVID-19 AND THE FoOd SySteM

\title{
Migrant farmworkers face heightened vulnerabilities during COVID-19
}

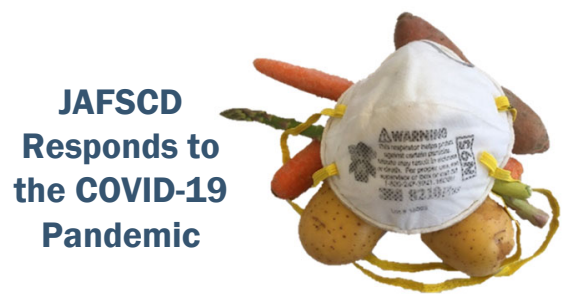

Ella Haley ${ }^{a *}$
Athabasca University

Susana Caxaj ${ }^{\text {b }}$

University of Western Ontario

Glynis George ${ }^{c}$

University of Windsor
Jenna L. Hennebry ${ }^{\mathrm{d}}$

Wilfrid Laurier University

Eliseo Martell, $\mathrm{MD}^{\mathrm{e}}$

Janet McLaughlin ${ }^{\mathrm{f}}$

Wilfrid Laurier University

Submitted April 23, 2020 / Published online May 1, 2020

Citation: Haley, E., Caxaj, S., George, G., Hennebry, J. L., Martell, E., \& McLaughlin, J. (2020). Migrant

farmworkers face heightened vulnerabilities during COVID-19. Journal of Agriculture, Food Systems, and

Community Development, 9(3), 35-39. https://doi.org/10.5304/jafscd.2020.093.016

Copyright (C 2020 by the Authors. Published by the Lyson Center for Civic Agriculture and Food Systems. Open access under CC-BY license.

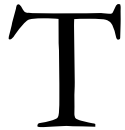
he COVID-19 pandemic has dramatically reshaped Canadian society in just a few short weeks. At the same time, its varied impacts shine a light on pre-existing social inequities. Certain populations, including low wage workers, racial minorities, homeless people, and older and disabled residents of long-term care facilities have been disproportionately impacted. One group that is particularly vulnerable to the effects of the crisis, yet has been largely neglected in discussions thus far, is the migrant worker population.

Each year over 50,000 migrant workers come to Canada through the Temporary Foreign Worker Program (TFWP)'s agricultural streams. The largest program stream within this, the Seasonal Agricultural Worker Program (SAWP), has been in place for over 50 years. SAWP brings in workers from Mexico and Commonwealth Caribbean countries for up to eight months a year to work in farms, green-

\footnotetext{
a $*$ Ella Haley, $\mathrm{PhD}$, Assistant Professor, Sociology, Athabasca University, Canada; ellah@athabascau.ca

b Susana Caxaj, PhD, Assistant Professor, School of Nursing, Faculty of Health Sciences, University of Western Ontario, Canada.

${ }^{c}$ Glynis George, PhD, Associate Professor, Sociology, Anthropology and Criminology, University of Windsor, Canada.
}

\footnotetext{
d Jenna L. Hennebry, PhD, Associate Professor and Senior Research Associate, International Migration Research Centre, Balsillie School of International Affairs, Wilfrid Laurier University, Canada.

e Eliseo Martell, MD, Canada.

${ }^{\mathrm{f} J a n e t}$ McLaughlin, PhD, Associate Professor, Health Studies, and Research Associate, International Migration Research Centre (IMRC), Balsillie School of International Affairs, Wilfrid Laurier University, Canada.
} 
houses, and orchards. These workers come without families and do not have a pathway to permanent residency. Migrant workers make up 10 percent of agricultural workers in Canada (Migrant Rights Network, n.d.).

The National Farmers Union (Dale, Fehr, \& Pfenning, 2020) publicized some of the key problems faced by temporary migrant agricultural workers amid the COVID-19 pandemic. In particular, they noted that the COVID-19 health crisis expose "deeper problems" in the seasonal worker program, and exposes the vulnerabilities of migrant farmworkers (MFWs). While Canada tightened its borders and restricted entry of most foreign nationals, temporary migrant workers were among those permitted entry. MFWs are deemed essential workers due to the central role they play in supporting Canadian farmers and the food supply. The government of Canada is facilitating the entry of MFWs to come and work in Canada in order to protect the viability of the agricultural industry and Canada's food system. However, it is critical that the rights and health of these workers are also protected.

The COVID-19 health crisis exposes systemic problems facing migrant workers, which have long been the target of criticism among experts working in the field (Hennebry, McLaughlin, \& Preibisch, 2016). Indeed, MFWs have long suffered from deep inequities, such as isolation, overcrowded living conditions, lack of access to field sanitation and personal protective equipment (PPE), ${ }^{1}$ difficulty accessing health care and workers' compensation, inability to switch employers, removal to countries of origin when ill or refusing unsafe or undesirable work, and lack of access to immigration pathways. Over the years, many MFWs have lost their jobs and were sent home when they became ill or injured (medical deportation) (Orkin, Lay, McLaughlin, Schwandt, \& Cole, 2014). MFWs have closed work permits, meaning they are tied to a specific employer. If they become ill from COVID-19, how will they fare with an unscrupulous employer or even an employer who is just trying to get their crops harvested and make a living in this fraught context? Will they be sent home? Will they lose their livelihoods? Will this fear prevent MFWs from seeking medical help, heightening the risk for themselves and other MFWs?

As previously noted, MFWs labor and live under conditions that pose risks to their health in a typical year, ranging from crowded housing to a lack of PPE, field sanitation, and handwashing stations on work sites. These vulnerabilities are only further magnified during the pandemic, placing them and their coworkers at increased risk of exposure to COVID-19 (Caxaj, Cohen et. al, 2020). Many live in tight quarters (e.g., trailers or bunkhouses) that are poorly ventilated, allowing for easy transmission of the virus, a pattern that has already emerged in prisons, meatpacking plants, long-term care homes, and homes for the disabled. To emphasize this point, Dale et al. (2020) note:

Migrant rights activists have long deplored the housing conditions that can be found on some farms. Some bunkhouses where migrant workers live are crowded and equipped with minimal bathroom facilities. Under the Federal standards for housing, employers must provide one toilet and sink per seven workers and one shower per ten workers. Most workers share large, dormitory-style rooms with six to eight workers meeting the minimum cubic volume of space required per worker. The chances for a virus to spread in such conditions are very high. (p. 16)

An outbreak exposing hundreds of workers in a greenhouse in British Columbia, resulting in 43 positive cases among migrant workers in Kelowna, has already demonstrated how susceptible migrants are in these circumstances (Rodrigues, 2020). British Columbia is trying to prevent further outbreaks by providing quarantine housing off the farm for MFWs who are returning to the province to work.

Additionally, many MFWs work long hours under difficult working conditions (e.g., rain, cold, heat),

${ }^{1}$ For example, when spraying pesticides 
with few or no days of rest during busy periods, making them vulnerable if they are exposed to COVID19.

Another concern is the wide variability in treatment by employers. Many exemplary employers would not tolerate abuses on their farms, such as Pfennings Organics, near Waterloo, Ontario, which has hired migrant workers for 15 years. The problem is that with tied work permits, workers cannot control where they are placed. Essentially, MFWs depend upon luck to work for a respectful employer. This program structure, which places so much control in the hands of the employer-with almost no meaningful recourse for workers if they are not well treated-is inherently problematic.

While migrant farmworkers have been excluded from immigration policies that privilege "skilled" workers, the pandemic has shifted the discourse to emphasize that migrant farmworkers are essential due to their expertise and skill. Will this recognition of the value and skill of migrant farmworkers transform the way we treat them in the future? Will the farmers' call for MFWs because they are "essential" and "skilled" help to enable open work permits, permanent residency status, and better working and housing conditions after the COVID-19 crisis?

\section{Protecting the Rights and Health of Migrant Farmworkers}

As part of a public health response to stop the spread of COVID-19, permitted international travelers to Canada, including MFWs are required to self-isolate for 14 days upon arrival (Quarantine Act, 2005). On April 13, 2020, the government has committed to providing financial support to employers to help cover the extra costs of adhering to procedures during the week in which many workers are already starting to arrive on farms. Farmers will receive CA $\$ 1,500$ per worker to provide suitable accommodation and supplement salaries to workers while they quarantine (Levitz, 2020). Yet critics have pointed out that without oversight and attention to where this money is directed, farmers-desperate to start the growing season-may pressure workers to work during the "quarantine" or "self-isolation" period.

Workers also need to be well supported to procure groceries, medications, and other necessities during this time. Currently, employers are responsible for arranging these logistics. However, some community organizations have already reported situations where workers arrive on farms with none of the amenities, food, or supplies needed when self-isolating or quarantining. Given the power imbalance between workers and their employers, not all workers will feel comfortable asking for assistance or reporting when they do not receive what they need (Caxaj \& Plamondon, 2020). There need to be clear procedures in place to ensure that all workers know their rights and responsibilities, along with safe mechanisms for reporting any concerns of violations without fear of risking their current or future employment.

In part to address such a power imbalances amid the current urgency of the COVID-19 pandemic, advocacy groups across Canada have called for full access to employment insurance (EI) for MFWs and opportunities for permanent residency. ${ }^{2}$ Many organizations, such as the Migrant Rights Network, the Canadian Council for Refugees, the Council of Canadians, labor groups, and Justicia for Migrant Workers, have called for significant changes that could help protect farmworkers" rights. The Migrant Rights Network, for example, has called on municipal, provincial, and federal governments to ensure justice for MFWs as part of the COVID-19 response. Some of their points most relevant to migrant farmworkers are:

1. Healthcare for All: "Access without fear" to free healthcare, including testing for COVID-19; "Enforce clear and precise guidelines to ensure language and community-specific accessible care. All

2 status on arrival. 
forms of medical repatriation (deportation) ... must end” (Migrant Rights Network, 2020, para. 2).

2. Worker Protections: Including adequate protective gear, "strong anti-reprisal protections for workers taking time off; income supports and open work permits for migrants who will lose wages or jobs because of sickness, quarantine or economic downturn . . . ; increased access to EI including special benefits; a federal emergency fund to provide [a] non-repayable allowance for those experiencing a loss or interruption of earnings including those outside Canada; and access to paid emergency leave as needed, with a minimum of 21 days for all workers, regardless of immigration status" (para. 3).

3. Stop Repatriations-Permanent Residency for All: The fear of medical deportation deters workers from seeking medical help. MFWs must be assured that they will not be prematurely repatriated for becoming ill..." (para. 4).

4. Support the Community: Fund community supports that serve migrant workers. "Clear policies and mechanisms must be created to stop the rise of xenophobia and racism. Communications about crisis response measures, including income support, must be made accessible to communities [e.g., Spanish, Thai ${ }^{3}$. Supports should also be directed towards poor and racialized people in the Global South"4 (para. 5).

5. Those That Know, Lead: "Migrant and community organizations should be included in planning and implementation of the current response to ensure that no one is left behind. Migrant .... workers, and their supporters, ... provide a road map out of this crisis and must be learned from" (para. 6).

The COVID-19 pandemic exposes how existing conditions of capitalism and systemic inequities render certain groups of workers structurally vulnerable to poor health impacts. Canada has deemed food production to be such an essential service that a travel exemption has been put in place to enable migrant workers, at the bottom rung of the agricultural labor hierarchy, to come and perform the arduous work that most Canadians reject. Should the people who perform this essential work not be treated with the dignity and rights commensurate with the importance of their labor? At the very least, such "essential workers" should have safe living and working conditions that do not place them at heightened risk of contracting COVID-19. Further, following the pandemic, the rights that these "essential" workers have been categorically denied must be finally recognized and protected.

\section{References}

Caxaj, S., Cohen, A., Colindres, C., Drolet, N., Hennebry, J., \& McLaughlin, J. (2020, April 21). Government COVID-19 guidelines gamble on the lives of migrant agricultural workers [Policy brief]. Canadian Science Policy Centre. Retrieved from https://sciencepolicy.ca/news/government-covid-19-guidelines-gamble-lives-migrant-agricultural-workers

Caxaj, C. S., \& Plamondon, K (2020, March 2). Nurses' role in improving health care access for migrant agricultural workers. Canadian Nurse. Retrieved from https://canadian-nurse.com/en/articles/issues/2020/march-2020/nurses-role-in-improving-health-care-access-formigrant-agricultural-workers

\footnotetext{
${ }^{3}$ MFWs need access to communication in order to even receive such messaging and information, and for many living in remote areas in the back of farm properties, internet and cellular access is limited and/or costly.

${ }^{4}$ Many MFWs will not return to work in Canada this year. Either their employers will not hire them back, or they will stay home due to concerns about COVID-19.
} 
Dale, B., Fehr, C., \& Pfenning, J. (2020). Knowing the borders of Canada's food system. Union Farmer Quarterly, 26(1): 16. Retrieved from https://www.nfu.ca/wp-content/uploads/2020/04/UFQ-SPRING-2020.pdf

Hennebry, J., McLaughlin, J., \& Preibisch, K. (2016). Out of the loop: (In)access to health care for migrant workers in Canada. Journal of International Migration and Integration, 17, 521-538. https://doi.org/10.1007/s12134-015-0417-1

Levitz, S. (2020, April 13). Farmers, food processors to get federal funds to help foreign workers isolate. CTV News. https://www.ctvnews.ca/health/coronavirus/farmers-food-processors-to-get-federal-funds-to-help-foreignworkers-isolate-1.4894063

Migrant Rights Network. (n.d.). Migrant \& worker justice demands: Coronavirus response must leave no one behind! Retrieved April 30, 2020, from https://migrantrights.ca/covid19/

Orkin, A. M., Lay, M., McLaughlin, J., Schwandt, M., Cole, D. (2014). Medical repatriation of migrant farm workers in Ontario: A descriptive analysis. CMAJ Open, 2(3): 192-198. https://doi.org/10.9778/cmajo.20140014

Quarantine Act, S.C. 2005, c. 20. Retrieved from https://laws-lois.justice.gc.ca/eng/acts/q-1.1/20200317/P1TT3xt3.html

Rodriguez, M. (2020, April 14). Three more cases of COVID-19 at Bylands Nurseries in West Kelowna. Lake Country Calendar. Retrieved from https://www.lakecountrycalendar.com/news/three-more-cases-of-covid-19-at-bylands-nurseries-in-west-kelowna/ 